\title{
Do Managers Of Global Equity Funds Outperform Their Respective Style Benchmarks? An Empirical Investigation
}

Heng-Hsing Hsieh, PhD, CFA, University of the Western Cape, South Africa Kathleen Hodnett, PhD, University of the Western Cape, South Africa

\begin{abstract}
Empirical literature suggests that stock-picking of fund managers do not provide economic benefits in addition to passively-replicated style benchmarks. This paper constructs a 4-factor style model using the Morgan Stanley Capital International (MSCI) World Index and the global size, value and momentum proxies to replicate the style benchmark returns of 12 activelymanaged global equity funds based on the return-decomposition approach of Sharpe (1992). In line with prior literature, it is found that the returns of the global equity funds under investigation are primarily driven by their respective style benchmarks. The selection returns of the analyzed funds are insignificant after adjustments for the inherent style risks. We thus conclude that active stock-picking of fund managers do not provide significant value in addition to asset and style allocation decisions.
\end{abstract}

Keywords: Style Analysis, Global Equity Funds, Return Decomposition, Active and Passive Portfolio Management, Value Investing, Momentum Investing

\section{INTRODUCTION}

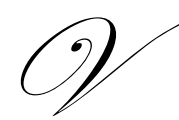

alue, size and momentum anomalies documented in empirical literature are pursued by active fund managers as the mainstream investment style that distinguishes their performance from the broad market index. In the competitive mutual fund industry, managers have further desire to distinguish their performance from their rivals who follow similar investment styles. They believe that this objective can be achieved via their superior stock-picking within the mandated style tilts. The merits of stock-picking are not supported by empirical evidence in that performance of actively-managed funds is found to be driven mainly by their underlying asset classes and style benchmarks rather than stock-picking. This paper undertakes to investigate whether actively-managed global equity funds outperform their respective style benchmarks.

Global equity funds have extended investment opportunities and benefits from international diversification compared to domestic equity funds. Their underlying investment styles can be replicated by analyzing their historical style allocations (that is, style tilts) to the pre-specified style proxies, and subsequently replicate their future performance using the same style allocations to the style proxies. The return on the replicated portfolio serves as the style benchmark mimicking the underlying investment styles of the global equity fund under investigation. The return decomposition approach of Sharpe (1992) is adapted for this purpose. This approach decomposes the time-series returns of the fund being analyzed to (i) the style return that is attributable to the returns on the style proxies and (ii) the selection return that cannot be explained by the movements in the returns of the pre-specified style proxies. As long as the fund return is primarily attributable to its style benchmark return and the selection return is random, active stock-picking does not provide additional benefits to a passively replicated style benchmark for the fund. 


\section{LITERATURE REVIEW}

The value effect is first documented in Basu (1977) who finds that stocks with high earnings yield (EY) outperform stocks with low earnings yield on the New York Stock Exchange (NYSE) over the period from 1957 to 1971. In addition to earnings yield, Lakonishok, Shleifer and Vishny (1994) find that stocks with high book-tomarket value (BTMV), cash flow-to-price (CFTP) and low historical sales growth outperform their growth counterparts with high price multiples on the New York Stock Exchange (NYSE) and the American Stock Exchange (AMEX) over the period from 1963 to 1990. Irrespective of their growth or value characteristics, firms with smaller market capitalization (small cap) are found to outperform their large cap counterparts. The size effect is documented by Banz (1981), Reinganum (1981, 1983) and Brown, Kleidon and Marsh (1983) on the NYSE. Fama and French (1992) consolidate empirical findings on the value and size anomalies and test both anomalies on the NYSE, AMEX and the National Association of Securities Dealers Automated Quotations (NASDAQ) over the period from 1963 to 1990. They find that book-to-market ratio and market capitalization are able to describe the cross-sectional equity returns over the examination period. Fama and French (1998) extend their tests to international economies and find the existence of a value effect in EAFE (Europe, Australia and Far East) stock portfolios over the period from 1975 to 1995. Chan and Lakonishok (2004) provide further evidence on the value anomaly in EAFE over the period from 1989 to 2001. The momentum effect, documented by Jegadeesh and Titman (1993), is another popular investment style followed by fund managers. Examining the returns to a relative strength strategy that acquires prior 3- to 12month winners on the NYSE and AMEX, Jegadeesh and Titman (1993) find the strategy profitable over the period from 1965 to 1989. Supporting evidence of the momentum effect are also documented by Schiereck, De Bondt and Weber (1999) on the Frankfurt Stock Exchange (FSE); Chan, Hameed and Tong (2000) on 23 global equity indices and Forner and Marhuenda (2003) on the Spanish Stock Exchange. Fama and French (1993) develop a 3-factor model using returns on the market, size and value proxies. The 3 -factor model is found to explain returns on all style portfolios with the exception of portfolios formed by short-term return momentum. Carhart (1997) includes an additional momentum proxy to Fama and French (1993) 3 -factor model and finds that the 4-factor model adequately explains style portfolio returns.

In an attempt to evaluate whether active stock-picking provides additional benefits to style and asset allocation decisions, Sharpe (1992) analyzes the performance of mutual funds in the U.S. over the period from 1985 through 1989. The 12 asset classes and style indices employed by Sharpe (1992) include the 90-day U.S. Treasury bill, the intermediate-term government bond index, the long-term government bond index, the corporate bond index, the mortgage-back security index, the large-cap value stock index, the large-cap growth stock index, the mediumcap stock index, the small-cap stock index, the non-U.S. government bond index, the European stock index and the Japanese stock index. The wide variety of the mutual funds (395 funds) covered by this research include growth funds, growth and income funds, utility funds and balanced funds. The results indicate that the return-based style decomposition method effectively explains the performances of U.S. mutual funds with out-of-sample $R$-squared of above $80 \%$ based on monthly-updates of the style exposures estimated over the prior 60 months. In addition, the selection returns of the funds under analysis are negative, on average, and statistically insignificant over the out-ofsample period. Sharpe (1992) concludes that the returns of the U.S. mutual funds are mainly driven by the performance of their underlying asset classes and investment styles rather than the manager's stock picking skills.

Fung and Hsieh (1998) conduct further analysis on the investment styles inherent in 2,525 mutual funds and 409 hedge funds in the U.S. over the period from 1991 to 1995. Fung and Hsieh (1998) extend the factor model of Sharpe (1992) by updating the identities of the factors in the model to incorporate the dynamics of the hedge fund industry. The location factors adapted by Fung and Hsieh (1998) include the MSCI U.S. Equity Index, the MSCI Non-U.S. Equity Index and the International Finance Corporation (IFC) Emerging Market Equity Index. Factors representing bond returns in this research include the JP Morgan Non-U.S. Government Bond Index and the Merrill Lynch High Yield Corporate Bond Index. The 1-month Eurodollar deposit rate is adapted as the cash return and the gold price is used to model commodity returns. The Federal Reserve's Trade-Weighted Dollar Index is used to model currency movements. The results of Fung and Hsieh (1998) indicate that additional factors extracted from factor analysis adequately capture the effects of dynamic hedge fund strategies and provide insight into the strategic difference between relative return styles for mutual funds and absolute return requirements for hedge funds. BaghaiWadji and Klocker (2007) analyze the performance of U.S. hedge funds from 1992 to 2004 using factors extracted from the cluster analysis based on a self-organising map (SOM) in a neural network that groups hedge funds into 
homogenous style-consistent categories. Their approach is based on the linear regression of Sharpe (1992) to replicate hedge fund performances while exploring the non-linearities in the regressors. The results confirm the failure of hedge fund managers to add value beyond the performances of their respective style benchmarks.

Ibbotson and Kaplan (2000) study the performance attribution of U.S. balanced funds over the period from 1988 to 1998. They regress the returns of the selected funds on the returns of the selected asset classes including U.S. large caps, U.S. small caps, non-U.S. stocks, U.S. bonds, cash and total equity. The results reveal that around $90 \%$ of the variations in fund returns are explained by these factors over time. The selection returns for the study appears to be insignificantly negative over the examination period. Vardharaj and Fabozzi (2007) conduct performance attribution studies on the U.S. equity funds and global equity funds over the period from 1995 to 2004. They find that over $90 \%$ of the variations in the U.S. and global equity fund returns are explained by the economic sector indices, size and value indices, and regional indices. Similar to the findings of Ibbotson and Kaplan (2000), Vardharaj and Fabozzi (2007) find that the performances of the selected funds are dominated by their asset allocation decisions with their selection returns being slightly negative over time.

The return decomposition methodology of Sharpe (1992) is also followed by Yu (2008), who analyses the return attribution of South African unit trusts over the period from 2001 to 2006. The factors adapted by Yu (2008) include three local sector indices, namely, the JSE Resource Index (RESI), the JSE Industrial Index (INDI), the JSE Financial Index (FINI), and three constructed style proxies, namely, the lag 11-month momentum proxy, the undervalued residual proxy and the equally-weighted top 100 size proxy. The out-of-sample regressions yield significant $R$-squared and the selection returns for the funds examined in this study are statistically insignificant. These findings support the argument of Sharpe (1992) that the performances of actively-managed funds are mainly attributed to their inherent investment styles, rather than fund managers' stock picking ability.

\section{RESEARCH DATA}

The research database from which style proxies are constructed is the Dow Jones (DJ) Sector Titans Composite Index. This composite consists of the largest 30 international stocks by U.S. dollar market capitalization from each of the 19 second tier Supersector structure defined by the Industry Classification Benchmark (ICB). These sectors include automobiles and parts, banks, basic resources, chemicals, construction and materials, financial services, food and beverages, healthcare, industrial goods and services, insurance, media, oil and gas, personal and household goods, real estate, retail, technology, telecommunication, travel and leisure and utilities. The DJ Sector Titans Composite Index provides broad coverage of the equities from the component sectors. Style indices constructed from this database have sufficient exposures to dimensions of risk inherent in the underlying industries of the database. Monthly total return index, stock price, number of outstanding stocks, market capitalization, book value per share, earnings per share, dividend per share, sales per share and cash flow per share of the 570 stocks comprising the DJ Sector Titans Composite Index over the period from 01 January 1996 to 31 December 2008 are downloaded from DataStream International as of 30 June 2010. All attributes are converted into U.S. dollars. Due to the fact that DataStream International only records data as the information becomes publicly available at the time without subsequently replacing data recorded with newly arrived information, the look-ahead bias is not present in the database. The style portfolios are constructed from the top 300 stocks in terms of their U.S. dollar market capitalization every month to ensure sufficient liquidity of the constituents of the style portfolios. This approach also reduces the effect of survivorship bias as large firms are less likely to be non-survivors in the market.

There are in total 12 internationally-domiciled global equity funds selected for this research. The selection criteria for this list are mainly based on the the diversity of the fund investment styles and the availability of the data. This list includes American Capital World Growth and Income Fund, American EuroPacific Growth Fund, BlackRock International Opportunities Portfolio, C-Quadrat - ARTS Best Momentum Fund, Federated Prudent Bear Fund, Fidelity Disciplined Equity Fund, Fidelity Diversified International Fund, Fidelity VIP Contrafund, Russell International Developed Markets Fund, SEI International Equity Fund, Skandia Global Equity Fund and Templeton World Fund. The monthly U.S. dollar-denominated returns for the selected funds are downloaded from the database of Bloomberg Limited Partnership in the research office of Salient Quantitative Investment Management (Pty) Ltd. The investments of the selected global equity funds are dominated by international equities. The selected funds are different in their intended style orientations and stated investment objectives. The inception 
date, U.S. dollar-denominated fund value as of 30 June 2010 and the fund objectives extracted from Bloomberg are displayed in Table 1.

Table 1: Global Equity Fund Descriptions

\begin{tabular}{|l||l||l|}
\hline \hline Fund Name: & Inception: & Market Value \\
\hline \hline 1. American Capital World Growth and Income Fund & $1993 / 03 / 26$ & \$75.60 Billion \\
\hline \hline
\end{tabular}

The fund's objective is long-term capital growth while providing current income. The fund invests primarily in stocks of wellestablished companies located around the world. The fund tends to invest in stocks that are believed to be relatively resilient to market declines.

\begin{tabular}{|c|c|c|}
\hline 2. American EuroPacific Growth Fund & 1984/04/16 & \$86.64 Billion \\
\hline
\end{tabular}

The fund's objective is long-term growth of capital. The fund invests at least $80 \%$ of its assets in securities of issuers located in Europe and the Pacific Basin. The fund may also hold cash, money market instruments and fixed income securities depending on market conditions.

\section{\begin{tabular}{|l||l||l|}
\hline 3. BlackRock International Opportunities Portfolio & $1997 / 09 / 26$ & \$1.54 Billion
\end{tabular}}

The fund's objective seeks long-term capital appreciation. The fund invests at least $80 \%$ of net assets in equity issued by international emerging capitalization companies. The fund may invest up to $25 \%$ of its net assets in stocks of issuers in emerging market countries.

\begin{tabular}{|l||l||l|}
\hline 4. C-QUADRAT - ART Best Momentum Fund & 1999/01/04 & \$46.63 Billion \\
\hline
\end{tabular}

The investment goal is long-term capital growth with a higher degree of risk. Investment decisions are generated by a computerbased trend-following trading programme. Fund selection is based on short and medium term momentum of price movements.
5. Federated Prudent Bear Fund
1995/12/28
\$1.15 Billion

The fund's objective is capital appreciation. The fund invests primarily through short sales of equity securities when overall market valuations are high and through long positions in value-oriented equity securities when overall market valuations are low.

\section{Fidelity Disciplined Equity Fund}

1988/12/28

\$10.32 Billion

The fund's objective is capital growth. The fund normally invests at least $80 \%$ of assets in equity securities. The fund seeks to reduce the impact of industry weightings on the performance of the fund relative to the S\&P 500 Index. The fund invests in domestic and foreign issuers

\section{Fidelity Diversified International Fund \\ 1991/12/27 \\ \$33.53 Billion}

The fund's objective is capital growth. The fund normally invests primarily in common stocks of non-U.S. issuers. The fund allocates its investments across countries and regions considering the size of the market in each country and region relative to the size of the international market.
8. Fidelity VIP Contrafund
1995/01/03
\$15.56 Billion

The fund's objective is capital appreciation. The fund invests primarily in the common stocks of domestic and foreign companies whose value is not fully recognized by the public. The fund invests in either "growth" stocks or "value" stocks or both.

\begin{tabular}{|c|c|c|}
\hline 9. Russell International Developed Markets Fund & 1983/01/31 & \$146.80 Billion \\
\hline
\end{tabular}

The fund's objective is to provide long-term capital growth. The fund invests primarily in equity securities issued by companies domiciled outside of U.S. and in depository receipts, which represent ownership of securities of non-U.S. companies.

\begin{tabular}{|l||l||l|l|}
\hline 10. SEI International Equity Fund & $1989 / 12 / 20$ & \$illion
\end{tabular}

The fund's objective is long-term capital appreciation. The fund invests at least $80 \%$ of its net assets in common stocks and other equity securities in at least three countries other than the United States.

\begin{tabular}{|l||l||l|}
\hline 11. Skandia Global Equity Fund & 2000/09/13 & \$262.61 Million
\end{tabular}

The fund's objective is capital growth. The fund will invest primarily in a well diversified portfolio of equity and equity related securities of issuers worldwide that are listed on recognized exchange.

\section{Templeton World Fund

1978/01/17 \\ \$5.85 Million}

The fund's objective is long-term capital growth. The fund invests mainly in the equity securities of companies located anywhere in the world, including emerging markets. The fund's total assets will be invested in issuers located in at least three different countries including the United States.

Source: Bloomberg database as of 01 March 2010 (adapted from Hsieh (2010))

\section{METHODOLOGY}

The research begins with the construction of global style proxies representing the size, value and momentum investments styles over the period from 1 January 1996 to 31 December 2008. Style proxies are rebalanced at the beginning of each month. The global size style proxy is constructed using top 100 stocks in terms 
of their U.S. dollar market capitalizations. The global value style proxy is constructed using top 100 stocks in terms of the average value of the five matrices, namely book value-to-market ratio, earnings yield, dividend yield, sales-toprice ratio and cash flow-to-price ratio. The global momentum proxy is constructed using the prior 12-month return momentum computed from the U.S. dollar total return index (inclusive of capital gains and dividend yield). In addition to the 3 pre-specified style proxies, we include the Morgan Stanley Capital International World Index (MSCI World) as the market proxy to capture systematic macroeconomic exposures in the global economy.

Adopting the return-decomposition approach of Sharpe (1992), historical style exposures (style weights) of the global equity funds under analysis are estimated based on Equation (1):

$$
r_{i, t}=\left[\left(w_{i, M S C I} \times r_{M S C I, t}\right)+\left(w_{i, \text { Size }} \times r_{\text {Size, },}\right)+\left(w_{i, \text { Mom }} \times r_{\text {Mom }, t}\right)+\left(w_{i, \text { Value }} \times r_{\text {Value }, t}\right)\right]+\varepsilon_{i, t}
$$

Where:

$r_{i, t}, r_{M S C I, t}, r_{\text {Size }, t}, r_{M o m, t}$ and $r_{\text {Value }, t}$

represent the returns on fund $i$, MSCI World Index, and the respective global style proxies in month $t$;

$w_{i, M S C I}, w_{i, \text { Size }}, w_{i, M o m}$ and $w_{i, \text { Value }} \quad$ represent fund $i$ 's style weights (exposures) for the MSCI World Index and the respective global style proxies; and

$\varepsilon_{i, t} \quad$ is the in-sample selection return for fund $i$ in month $t$ that is not explained by fund $i$ 's exposures to the returns on the MSCI World Index and the global style proxies.

Equation 1 is intended to provide an indication of the passive mix of the fund's underlying investment styles without involvements in leverage and short-selling the pre-specified proxies. This objective is achieved by restricting the style exposures to be in between $0 \%$ and $100 \%$ in the equation. The sum of the terms in the squared bracket of Equation 1 represents the in-sample style benchmark return of the fund. The error term of the regression, on the other hand, is the in-sample selection return of the fund that is not explained by its style benchmark. Thus, the selection return represents the deviation of the fund performance from its style benchmark, and the variance of the selection return is regarded as the fund's tracking error. Based on Equation 1, a series of rolling 36-month weighted least squares (WLS) regressions are performed monthly for each of the selected funds over the examination period starting from the earliest month for which the return data of the respective funds are available. The WLS regression allocates a weight to the fund return in each month equivalent to $2^{1 / 36}$ times the weight assigned to its predecessor in the previous month, starting with the weight of 1.0 assigned to the return in the first month. This approach effectively places greater emphasis on more recent returns relative to more distant returns. The objective of the WLS regression is to minimise the variance of the error term in Equation 1, which is equivalent to minimising the fund's weighted tracking error.

Once the style weights of the selected global equity funds are estimated over the examination period, the replication of the fund's underlying investment style begins by constructing a style benchmark that adjusts its allocations in the style proxies monthly based on the most recent prior estimates of the fund's style weights. The out-of-sample style benchmark return is estimated monthly using Equation 2:

$$
\tilde{r}_{i, S t y l e, t}=\left(\tilde{w}_{i, M S C I, t} \times r_{\text {MSCI }, t}\right)+\left(\tilde{w}_{i, \text { Size }, t} \times r_{\text {Size }, t}\right)+\left(\tilde{w}_{i, \text { Mom }, t} \times r_{\text {Mom }, t}\right)+\left(\tilde{w}_{i, \text { Value }, t} \times r_{\text {Value }, t}\right)
$$

Where:

$\sim$

$r_{i, \text { Style,t }}$

represents the out-of-sample style benchmark return for fund $i$

$\tilde{w}_{i, M S C I, t}, \tilde{w}_{i, S i z e, t}, \tilde{w}_{i, M o m, t}$ and $\tilde{w}_{i, \text { Value }, t}$ in month $t$; and

represent the respective out-of-sample style exposure estimates for fund $i$ in month $t$ computed using return data from month $t-36$ through month $t-1$ based on Equation 1.

Thus, the monthly out-of-sample selection return is the difference between the fund's actual return and its 
estimated style benchmark return as shown by Equation 3:

$\tilde{\varepsilon}_{i, t}=r_{i, t}-\tilde{r}_{i, S t y l e, t}$

The average out-of-sample style benchmark return and the selection return for each of the selected funds are computed. In addition, the out-of-sample Sharpe ratios for the funds and their respective style benchmarks are computed using Equation 4 to evaluate the fund performance on a risk-adjusted basis. The style factor model shown in Equation 5 is then employed to evaluate the style risk-adjusted performance of the global equity funds and the ability of the style benchmark in tracking the actual fund returns over the out-of-sample period:

$$
\text { Sharpe Ratio }_{P}=\frac{R_{P}-R_{f}}{\sigma_{P}}
$$

Where:

$R_{P} \quad$ is the return on portfolio $P$ over the evaluation period;

$\sigma_{P} \quad$ is the standard deviation of portfolio $P$ 's return over the evaluation period; and

$R_{f} \quad$ is the risk-free proxy (U.S. 3-month Treasury yield is employed for this purpose).

$$
r_{i, t}=\alpha_{i}+b_{i, \text { Style }} \times \tilde{r}_{i, \text { Style }, t}+e_{i, t}
$$

Where:

$\alpha_{i} \quad$ is the regression constant that is not explained by fund $i$ 's style risk;

$b_{i, S t y l e} \quad$ is the sensitivity of fund $i$ 's return to movements in the style benchmark return; and

$e_{i, t} \quad$ is the random error of the regression that is not explained by the style benchmark.

\section{EMPIRICAL FINDINGS}

The summarised return attributions of the global equity funds are presented in Table 2. Under the heading "Performance Attribution", the average fund return is decomposed into (1) average style benchmark return and (2) average selection return over the evaluation period. The average style benchmark return is estimated by Equation 2. The average selection return is the difference between the actual fund return and the average style benchmark return as estimated by Equation 3. Comparing the average fund returns to their respective average style benchmark returns reveal that 6 out of 12 funds manage to earn higher returns relative to their style benchmarks (American Capital World Growth and Income Fund, American EuroPacific Growth Fund, C-Quadrat ARTs Best Momentum Fund, Federated Prudent Bear Fund, Fidelity Diversified International Fund and Russell International Developed Markets Fund). The managers of these 6 funds thus provide positive selection return through their stock-picking activities. However, when the funds are evaluated on risk-adjusted basis, the number of outperforming funds reduced to 4 (American Capital World Growth and Income Fund, American EuroPacific Growth Fund, C-Quadrat ARTS Best Momentum Fund and Federated Prudent Bear Fund). This implies that stock-picking activities of active managers might introduce inadequate volatility to the portfolio. It is also noted that the Sharpe ratio of Skandia Global Equity Fund's style benchmark remains positive even when the Sharpe ratio of the fund is negative over the evaluation period.

The out-of-sample regression results obtained from Equation 5 are presented under the heading "Style Return Contribution". The Student $t$-statistics for the regression intercepts and slope coefficients are shown in parenthesis. Statistically significant intercepts and slope coefficients are highlighted in bold. R-squared of the regression indicates the percentage of fund return that is predicted by the style-based factor model. A high Rsquared value indicates that the majority of the fund returns is explained by its style benchmark. The R-squared for all regressions are above 50\% with the exception of C-Quadrat ARTS Best Momentum Fund and Federated Prudent Bear Fund. The intercept of the regression represents consistent outperformance/underperformance of the fund over its style risk-adjusted return. The slope coefficient of the regression measures the fund's style risk as the sensitivity of the fund's return to movements in the style benchmark return. A slope coefficient of 1.50 means that the fund 
return will increase by $1.50 \%$ when the style benchmark return goes up by $1.00 \%$. American Capital World Growth and Income Fund, American EuroPacific Growth Fund, Fidelity Diversified International Fund, Russell International Developed Markets Fund and SEI International Equity Fund are the 5 funds that exhibit greater than 1.00 for their slope coefficient. On the other hand, BlackRock International Opportunities Portfolio, C-Quadrat ARTS Best Momentum Fund, Fidelity Disciplined Equity Fund, Fidelity VIP Contrafund, Skandia Global Equity Fund and Templeton World Fund exhibit relatively lower style risk. Federated Prudent Bear Fund is the only fund that exhibits negative slope coefficient. In addition, it is also the only fund that earns significant abnormal return (as indicated by the intercept of the regression) over its style risk-adjusted return over the evaluation period. This evidence reflects its contrarian-like investment objective. Overall, all funds under analysis exhibit statistically significant slope coefficients coupled with high R-squared values, which reflect the appropriateness of their respective style benchmarks in representing their unique exposures to style risk.

Table 2: Return Attribution of Global Equity Funds

\begin{tabular}{|c|c|c|c|c|c|c|}
\hline Period: & $\begin{array}{l}\text { American } \\
\text { Capital Wld. } \\
\text { Growth and } \\
\text { Income Fund } \\
2002-2008\end{array}$ & $\begin{array}{l}\text { American } \\
\text { EuroPacific } \\
\text { Growth Fund } \\
\text { 2002-2008 }\end{array}$ & $\begin{array}{l}\text { BlackRock } \\
\text { International } \\
\text { Opportunity } \\
\text { Portfolio } \\
\text { 2003-2008 } \\
\end{array}$ & $\begin{array}{l}\text { C-Quadrat } \\
\text { ARTS Best } \\
\text { Momentum } \\
\text { Fund } \\
\text { 2002-2008 }\end{array}$ & $\begin{array}{l}\text { Federated } \\
\text { Prudent Bear } \\
\text { Fund } \\
\text { 2002-2008 }\end{array}$ & $\begin{array}{l}\text { Fidelity } \\
\text { Disciplined } \\
\text { Equity Fund } \\
2002-2008 \\
\end{array}$ \\
\hline $\begin{array}{l}\text { Performance } \\
\text { Attribution } \\
\text { Avg. Fund R\% } \\
\text { Sharpe Ratio }\end{array}$ & $\begin{array}{l}1.60 \% \\
0.194 \\
\end{array}$ & $\begin{array}{l}1.51 \% \\
0.170 \\
\end{array}$ & $\begin{array}{l}0.55 \% \\
0.065 \\
\end{array}$ & $\begin{array}{l}2.11 \% \\
0.236 \\
\end{array}$ & $\begin{array}{l}0.88 \% \\
0.107 \\
\end{array}$ & $\begin{array}{l}0.55 \% \\
0.050 \\
\end{array}$ \\
\hline $\begin{array}{l}\text { (1) } \\
\text { Avg. Style R\% } \\
\text { Sharpe Ratio }\end{array}$ & $\begin{array}{l}0.97 \% \\
0.146 \\
\end{array}$ & $\begin{array}{l}1.03 \% \\
0.156\end{array}$ & $\begin{array}{l}0.98 \% \\
0.143\end{array}$ & $\begin{array}{l}0.88 \% \\
0.126\end{array}$ & $\begin{array}{l}0.53 \% \\
0.059 \\
\end{array}$ & $\begin{array}{l}0.75 \% \\
0.105 \\
\end{array}$ \\
\hline $\begin{array}{l}\text { (2) } \\
\text { Avg.Select.R\% }\end{array}$ & $0.62 \%$ & $0.48 \%$ & $-0.43 \%$ & $1.22 \%$ & $0.35 \%$ & $-0.21 \%$ \\
\hline $\begin{array}{l}\text { Style Return } \\
\text { Contribution } \\
\text { R Squared } \\
\text { Intercept }\end{array}$ & $\begin{array}{l}60.46 \% \\
0.006 \\
{[1.065]}\end{array}$ & $\begin{array}{l}61.16 \% \\
0.003 \\
{[0.594]}\end{array}$ & $\begin{array}{l}82.27 \% \\
-0.003 \\
{[-1.138]}\end{array}$ & $\begin{array}{l}38.74 \% \\
0.013 \\
{[1.742]}\end{array}$ & $\begin{array}{l}39.99 \% \\
\mathbf{0 . 0 1 3} \\
{[2.299]}\end{array}$ & $\begin{array}{l}54.60 \% \\
-0.002 \\
{[-0.315]}\end{array}$ \\
\hline $\begin{array}{l}\text { Slope } \\
\text { Coefficient }\end{array}$ & $\begin{array}{l}1.067 \\
{[10.637]}\end{array}$ & $\begin{array}{l}1.146 \\
{[10.795]}\end{array}$ & $\begin{array}{l}0.854 \\
{[17.894]}\end{array}$ & $\begin{array}{l}0.941 \\
{[6.841]}\end{array}$ & $\begin{array}{l}-0.747 \\
{[-7.022]}\end{array}$ & $\begin{array}{l}0.939 \\
{[9.433]}\end{array}$ \\
\hline Period: & $\begin{array}{l}\text { Fidelity } \\
\text { Diversified } \\
\text { International } \\
\text { Fund } \\
\text { 2002-2008 } \\
\end{array}$ & $\begin{array}{l}\text { Fidelity VIP } \\
\text { Contrafund } \\
\text { 2002-2008 } \\
\end{array}$ & $\begin{array}{l}\text { Russell } \\
\text { International } \\
\text { Developed } \\
\text { Mkt. Fund } \\
\text { 2002-2008 } \\
\end{array}$ & $\begin{array}{l}\text { SEI } \\
\text { International } \\
\text { Equity Fund } \\
\text { 2002-2008 }\end{array}$ & $\begin{array}{l}\text { Skandia } \\
\text { Global Equity } \\
\text { Fund } \\
\text { 2003-2008 }\end{array}$ & $\begin{array}{l}\text { Templeton } \\
\text { World Fund } \\
\text { 2002-2008 }\end{array}$ \\
\hline $\begin{array}{l}\text { Performance } \\
\text { Attribution } \\
\text { Avg. Fund R\% } \\
\text { Sharpe Ratio } \\
\end{array}$ & $\begin{array}{l}1.36 \% \\
0.139 \\
\end{array}$ & $\begin{array}{l}0.82 \% \\
0.091 \\
\end{array}$ & $\begin{array}{l}1.12 \% \\
0.111 \\
\end{array}$ & $\begin{array}{l}0.63 \% \\
0.047 \\
\end{array}$ & $\begin{array}{l}0.21 \% \\
-0.007 \\
\end{array}$ & $\begin{array}{l}0.46 \% \\
0.053\end{array}$ \\
\hline $\begin{array}{l}\text { (1) } \\
\text { Avg.Style R\% } \\
\text { Sharpe Ratio }\end{array}$ & $\begin{array}{l}0.97 \% \\
0.143\end{array}$ & $\begin{array}{l}0.93 \% \\
0.135\end{array}$ & $\begin{array}{l}0.95 \% \\
0.144\end{array}$ & $\begin{array}{l}0.94 \% \\
0.144\end{array}$ & $\begin{array}{l}0.74 \% \\
0.091 \\
\end{array}$ & $\begin{array}{l}1.03 \% \\
0.156\end{array}$ \\
\hline $\begin{array}{l}\text { (2) } \\
\text { Avg.Select.R\% }\end{array}$ & $0.40 \%$ & $-0.10 \%$ & $0.17 \%$ & $-0.31 \%$ & $-0.52 \%$ & $-0.57 \%$ \\
\hline $\begin{array}{l}\text { Style Return } \\
\text { Contribution } \\
\text { R Squared } \\
\text { Intercept }\end{array}$ & $\begin{array}{l}62.72 \% \\
0.002 \\
{[0.266]}\end{array}$ & $\begin{array}{l}58.81 \% \\
0.003 \\
{[0.594]}\end{array}$ & $\begin{array}{l}62.64 \% \\
-0.003 \\
{[-1.138]}\end{array}$ & $\begin{array}{l}60.66 \% \\
-0.006 \\
{[-1.000]}\end{array}$ & $\begin{array}{l}78.80 \% \\
-0.004 \\
{[-0.288]}\end{array}$ & $\begin{array}{l}78.22 \% \\
-0.003 \\
{[-1.362]}\end{array}$ \\
\hline $\begin{array}{l}\text { Slope } \\
\text { Coefficient }\end{array}$ & $\begin{array}{l}1.250 \\
{[11.158]}\end{array}$ & $\begin{array}{l}0.964 \\
{[10.280]}\end{array}$ & $\begin{array}{l}1.255 \\
{[11.138]}\end{array}$ & $\begin{array}{l}1.352 \\
{[10.681]}\end{array}$ & $\begin{array}{l}0.777 \\
{[15.060]}\end{array}$ & $\begin{array}{l}0.781 \\
{[16.301]}\end{array}$ \\
\hline
\end{tabular}




\section{CONCLUSION}

In this paper style benchmarks are constructed for 12 actively-managed global equity funds. The benchmarks allocates weights to its underlying style proxies namely the MSCI World Index, the global size proxy, the global value proxy and the global momentum proxy. Adopting the style-decomposition approach of Sharpe (1992), the style benchmark estimates monthly style allocations of the global equity funds based on their prior 36month style allocations using weighted least squares regressions. The performances of the actively-managed funds are subsequently evaluated against the performances of their respective style benchmarks.

When the average return of the global equity funds are compared to the average returns of their respective style benchmarks, 6 out of 12 funds earn return above their style benchmark returns with positive average selection returns. This number is reduced to 4 out of 12 when the performance is evaluated on risk-adjusted basis measured by the Sharpe ratio. This result suggests that active managers might introduce inappropriate risks through their stockpicking activities. In addition, when fund returns are regressed on their respective style benchmark returns, it is found that the majority of the global equity fund returns are attributed to their style benchmark returns with high Rsquared and significant style coefficients. This serves as evidence that the style proxies employed by this research are appropriate in representing the underlying dimensions of style risk inherent in the global equity funds under analysis. Most of the global equity funds exhibit statistically insignificant regression intercepts. This finding suggests that the positive selection returns earned by the global equity funds under analysis are mostly inconsistent over time.

In summary, in line with empirical literature, this paper finds little evidence that managers of global equity funds add value to the performance of their passively replicated style benchmarks through stock-picking. With limited contribution from the selection return to the actual fund return, the performance of the style benchmark serves as an unbiased estimate of the performance of the fund being replicated. The empirical investigations of the time-series style allocations of the global equity funds is recommended for further research to determine whether funds are managed according to the stated mandates regarding their style orientation.

\section{ACKNOWLEDGEMENT}

This work is supported by the National Research Foundation of South Africa. We wish to thank the research office of the University of the Western Cape for their support. Additionally, we wish to thank Professor Paul van Rensburg from the University of Cape Town for the use of Bloomberg research database at SalientQuants Investment Management and his special insights and assistance in this topic.

\section{AUTHOR INFORMATION}

Dr. Heng-Hsing Hsieh, CFA is currently a Senior Lecturer in the School of Business and Finance at the University of the Western Cape, South Africa. He is a CFA charterholder and a Registered Person on the JSE Securities Exchange (RPE). E-mail: ahsieh@uwc.ac.za. Corresponding Author.

Dr. Kathleen Hodnett is currently a Research Fellow (funded by the National Research Foundation (NRF) of South Africa) in the School of Business and Finance at the University of the Western Cape, South Africa.

\section{REFERENCES}

1. Baghai-Wadji R and Klocker S (January 2007), Performance and Style Shifts in the Hedge Fund Industry, London Business School, Working Paper, 1-48

2. Banz R W (1981), "The Relationship between Return and Market Value of Common Stocks", Journal of Financial Economics, no 9, 3-18

3. Basu S (1977), "The Investment Performance of Common Stocks in Relation to Their Price to Earnings Ratio: A Test of the Efficient Markets Hypothesis", Journal of Finance, vol 32, no 3, 663-682

4. Brown P, Kleidon A W and Marsh T A (1983), "New Evidence on the Nature of Size-Related Anomalies in Stock Prices", Journal of Financial Economics, no 12, 33-56 
5. Carhart M (1997), “On persistence of mutual fund performance”, Journal of Finance, no 52, 57-82

6. Chan K C, Hameed A and Tong W (June 2000), "Profitability of Momentum Strategies in the International Equity Markets", The Journal Financial and Quantitative Analysis, vol 35, no 2, 153-172

7. Chan L K C and Lakonishok J (January/February 2004), "Value and Growth Investing: Review and Update", Financial Analysts Journal, vol 60, no 1, 71-86

8. Fama E F and French K R (1992), “The Cross-Section of Expected Stock Returns", Journal of Finance, vol 47, 427-465

9. Fama E F and French K R (1993), "Common Risk Factors in the Returns on Stocks and Bonds", Journal of Financial Economics, vol 33 no 1, 3-56

10. Fama E F and French K R (1998), "Value Versus Growth: The International Evidence", Journal of Finance, vol 53, no 6, 1975-1999

11. Forner C and Marhuenda J (2003), "Contrarian and Momentum Strategies in the Spanish Stock Market Seasonality", Journal of Finance, vol 42, no 3, 557-581

12. Hodnett K (2010), “Analysis of the Cross-Section of Equity Returns on the JSE Securities Exchange based on Linear and Nonlinear Modeling Techniques", Unpublished Doctoral Thesis, University of Cape Town

13. Hsieh H (2010), "Applications of Global Equity Style Indices in Active and Passive Portfolio Management", Unpublished Doctoral Thesis, University of Cape Town

14. Ibbotson R D and Kaplan P (2000), "Does Asset Allocation Policy Explain 40, 90, or 100 Percent of Performance?", Financial Analysts Journal, vol 56, no 1, 26-33

15. Jegadeesh N and Titman S (March 1993), "Returns to Buying Winners and Selling Losers: Implications for Stock Market Efficiency", Journal of Finance, vol 48, no 1, 65-91

16. Fung W and Hsieh D A (1998), "Performance Attribution and Style Analysis: From Mutual Funds to Hedge Funds", Paradigm Financial Products, Principal Publisher

17. Reinganum M R (1981), "Misspecification of Capital Asset Pricing - Empirical Anomalies Based on Earnings' Yields and Market Values", Journal of Financial Economics, no 9, 19-46

18. Reinganum M R (1983), "The Anomalous Stock Market Behavior of Small Firms in January - Empirical Tests for Tax-Loss Selling Effects", Journal of Financial Economics, no 12, 89-104

19. Schiereck D, De Bondt W F M and Weber M (1999), "Contrarian and Momentum Strategies in Germany", Financial Analysts Journal, vol 55, no 6, 104-116

20. Sharpe W F (1992), “Asset Allocation: Management Style and Performance Measurement”, Journal of Portfolio Management, vol 18, 7-19

21. Vardharaj R and Fabozzi F J (2007), "Sector, Style, Region: Explaining Stock Allocation Performance”, Financial Analysts Journal, vol 63, no 3, 59-70

22. Yu X (2008), Style Indices and Active Portfolio Construction on the JSE, University of Cape Town, Working Paper 


\section{NOTES}

